\title{
GANGGUAN BERBICARA PADA PENYANDANG TUNARUNGU DI CINERE DEPOK
}

\author{
Mardiana $^{1}$, Tri Pujiati ${ }^{2}$ \\ Program Studi Sastra Indonesia, Universitas Pamulang \\ nmardianna@gmail.com ${ }^{l}$; tpujiati.unpam@gmail.com ${ }^{2}$
}

\begin{abstract}
Abstrak
Penelitian ini bertujuan untuk (1) mengetahui tuturan fonologi pada penyandang tunarungu di Cinere Depok (2) mendeskripsikan bentuk bahasa isyarat pada penyandang tunarungu di Cinere Depok. Penelitian ini menggunakan pendekatan kualitatif dengan subjek penelitian yaitu subjek tunggal usia 22 tahun. Hasil penelitian menunjukan bahwa subjek tunggal usia 22 tahun yang juga mengalami gangguan berbicara dan seorang penyandang tunarungu mampu melafalkan huruf vokal dengan baik, meskipun pada huruf konsonan ada beberapa huruf yang dilafalkan berubah seperti huruf $\mathrm{B}$ berubah menjadi $\mathrm{P}, \mathrm{E}$ berubah menjadi $\mathrm{R}, \mathrm{G}$ berubah menjadi $\mathrm{E}, \mathrm{K}$ berubah menjadi $\mathrm{A}$, Q berubah menjadi $\mathrm{U}, \mathrm{R}$ berubah menjadi L, V berubah menjadi $\mathrm{P}, \mathrm{W}$ berubah menjadi $\mathrm{V}$, dan $\mathrm{X}$ berubah menjadi $\mathrm{S}$. Pada wawancara ada huruf yang dilafalkan berubah seperti E, S, R, K, dan A serta hilang huruf seperti K, O, N, H, G, R, E, S, Y, B, A, I, dan T. Sedangkan pada bahasa isyarat dari subjek tunggal ini sudah sesuai dengan Bahasa Isyarat Indonesia (BISINDO).
\end{abstract}

Kata kunci: Psikolinguistik, Gangguan Berbicara, Tunarungu, Fonologi, dan Bahasa Isyarat

\begin{abstract}
This study aims to (1) know the phonological speech on the deaf in Cinere Depok (2) describe the sign language form for the deaf in Cinere Depok. This study used a qualitative approach with the subject of the research is the subject single aged 22 years. The results showed that a single 22-year-old subject who also suffered from speech impairment and a deaf person was able to pronounce vowels well, although in consonant letters some letters were pronounced as $B$ changed into $P, E$ changed into $R$, $G$ changed into $E, K$ turns into $A, Q$ turns into $U, R$ turns into $L, V$ turns into $P, W$ turns into $V$, and $X$ turns into $S$. In interviews there are letters that are pronounced changed like $E, S, R, K$, and $A$ as well as missing letters such as $K, O, N, H, G, R, E, S, Y, B, A, I$, and $T$. While the sign language of this single subject is in conformity with Indonesian Sign Language (BISINDO).
\end{abstract}

Keywords: Psycholinguistics, Speech Disorder, Deaf, Phonology, and Sign Language

\section{PENDAHULUAN}

Bahasa merupakan sebuah rangkaian dari mendengar, bicara, membaca, dan menulis. Bahasa mempunyai fungsi yang sangat penting bagi manusia, terutama fungsi komunikasi. Keraf (1997: 1) berpendapat bahwa bahasa ialah alat komunikasi antara anggota masyarakat berupa simbol bunyi yang dihasilkan oleh alat ucap manusia. Kemampuan bahasa yang dimiliki manusia untuk berkomunikasi dengan manusia lainnya menggunakan tanda, misalnya kata dan gerakan. Bahasa alami adalah bicara atau bahasa isyarat, tetapi setiap bahasa dapat disandikan ke dalam media kedua menggunakan stimulus audio, visual, atau taktil. Hal ini karena bahasa manusia bersifat independen terhadap modalitas. Bahasa yang kita kenal yaitu ada dua, bahasa verbal dan non-verbal. 
Bahasa itu sendiri masuk ke dalam ilmu bahasa atau biasa disebut linguistik, dalam berbahasa sehari-hari, manusia mengalami proses yang namanya bahasa dan berbahasa.

Menurut Chaer (2003: 5) Proses bahasa dan berbahasa adalah dua hal yang berbeda. Bahasa adalah alat verbal yang digunakan untuk berkomunikasi, sedangkan berbahasa sendiri adalah proses menyampaikan informasi dalam berkomunikasi itu. Proses berbahasa adalah proses mental yang terjadi pada waktu kita berbicara ataupun proses mental yang menjadi dasar pada waktu kita mendengar, mengerti, dan mengingat dapat diterangkan dengan suatu sistem kognitif yang ada pada manusia.

Manusia mempunyai suatu sistem penggunaan bahasa dan psikologi bahasa yang mempelajari cara kerja dari proses sistem ini. Sistem ini dapat menerangkan sesuatu misalnya, bagaimana manusia dapat menyampaikan pikiran dengan kata-kata (produksi bahasa) dan bagaimana manusia mengerti isi pikiran atau makna dari suatu kalimat yang diucapkan atau ditulis (persepsi bahasa). Setelah manusia menyampaikan pikiran kemudian mengerti isi pikiran atau makna dari suatu kalimat tersebut, maka selanjutnya proses akal manusia akan mulai bekerja sehingga otak akan mencerna kemudian melakukan perintah dari apa yang disampaikan dan dimengerti oleh otak. Tahapan ini mengenai kajian interdisipliner dari linguistik yaitu psikoinguistik.

Psikolinguistik sebenarnya adalah gabungan antara dua ilmu: psikologi dan linguistik. Benih ilmu ini sebenarnya sudah tampak pada permulaan abad ke-20 tatkala sarjana psikologi Jerman, Wilhelm Wundt menyatakan bahwa bahasa dapat dijelaskan dengan dasar prinsip-prinsip psikologis. Pada waktu itu kajian bahasa mengalami perubahan daripada sifatnya yang estetik dan kultural ke suatu pendekatan yang ilmiah. Perkembangan ini dapat dibagi ke empat tahap: (a) tahap formatif, (b) tahap linguistik, (c) tahap kognitif, dan (d) tahap teori psikolinguistik, realiti psikologi, dan ilmu kognitif. (Kess, 1992 dalam Dardjowidjojo, 2003: 3).

Proses akal atau proses pikiran seseorang itu biasanya menggunakan bahasa, karena bahasa merupakan suatu syarat untuk dapat berpikir. Dengan kata lain, bahwa proses akal atau proses pikiran seseorang itu tergantung pada bahasanya, artinya struktur bahasanyalah yang menentukan proses akal atau struktur pikiran seseorang itu. Meskipun ada pula yang berpendirian sebaliknya, justru proses akal atau proses pikiran itulah yang menentukan aspek-aspek kebahasaan seseorang. Jean Piaget mengatakan bahwa struktur pikiran seseorang dibentuk oleh aksi atau perilaku kanak-kanak dan bukan oleh struktur bahasa, artinya struktur pikiran mendahului kebolehan-kebolehan yang dipakai kemudian untuk berbahasa. (Teori Pertumbuhan Kognisi Jean Piaget, 1962 dalam Suriasumantri, 1998).

Dalam kehidupan bermasyarakat ada manusia yang terlahir dengan keadaan normal dan ada pula manusia yang terlahir tidak dalam keadan normal, dan ada pula manusia yang terlahir dengan keadaan normal namun setelah itu mengalami kecacatan atau sistem kognitifnya tdak berkembang. Sebagian orang yang mengalami keterbatasan dalam dirinya ini membuat kehidupan-nya terhalang. Akibat keterbatasannya ini sering pula disebut dengan orang yang memiliki kebutuhan khusus. Orang yang memiliki kebutuhan khusus ini tidak pasti pada mereka yang mengalami kecacatan pada fisiknya saja, tetapi juga pada mereka yang mengalami kerusakan pada syaraf- 
syarafnya. Kecacatan dan kerusakan ini terjadi bisa dari faktor keturunan, kecelakaan, lingkungan, maupun gaya hidup yang tak sehat.

Kecacatan dan kerusakan syaraf tersebut mengakibatkan si penderita terganggu bahasa, bicara, dan komunikasinya dengan orang lain. Hal ini dapat mempersulit orang lain untuk mengerti bahasa mereka karena kecacatan dan kerusakan syaraf tersebut. Pada zaman yang serba modern ini sudah banyak cara untuk mempermudah orang-orang berkebutuhan khusus untuk berkomunikasi atau berinteraksi dengan orang lain, salah satunya dengan melakukan terapi.

Di dalam kenyataannya baik gangguan berbahasa, berbicara, komunikasi maupun pendengaran pada dasarnya satu kesatuan yang berhubungan dengan bahasa yang digunakan manusia untuk berinteraksi dengan manusia lainnya. Namun, sebenarnya apapun gangguannya itu tidaklah menghalangi atau membatasi diri kita untuk tak mengenal orang-orang yang mengalami gangguan tadi. Salah satu gangguan yang sering terjadi di masyarakat adalah gangguan pendengar-an dan berbicara.

Menurut Khabori dan Khandekar: (2004), gangguan pendengaran adalah kehilangan pendengaran di salah satu atau kedua telinga. Tingkat penurunan gangguan pendengaran terbagi menjadi ringan, sedang, sedang berat, berat, dan sangat berat. Proses pendengaran terjadi ketika gendang telinga bergetar akibat gelombang suara yang masuk ke dalam telinga. Getaran kemudian dilanjutkan ke telinga tengah melalui tiga tulang pendengaran yang dikenal dengan nama osikel. Osikel akan memperkuat getaran untuk dilanjutkan menuju rambutrambut halus di dalam koklea, di mana koklea akhirnya mengirim sinyal melalui saraf pendengaran ke otak.
Biasanya gangguan pendengaran berkembang secara bertahap, tapi hilangnya pendengaran bisa muncul tiba-tiba.

Untuk mengungkapkan istilah tersebut, maka istilah tunarungu yang dipakai. Istilah tunarungu ini digunakan untuk mereka yang tidak bisa mendengar dengan jelas atau mendengar tapi samar-samar. Tunarungu juga bisa disebut tuli, karena tuli adalah gangguan yang terjadi pada alat pendengaran (disaudia). Winarsih, (2007: 23), menyatakan tunarungu adalah seseorang yang mengalami kekurangan atau kehilangan kemampuan mendengar baik sebagian atau seluruhnya yang diakibatkan oleh tidak fungsinya sebagian atau seluruh alat pendengaran, sehingga anak tersebut tidak dapat menggunakan alat pendengarannya dalam kehidupan sehari-hari.

Berbicara merupakan aktivitas motorik yang mengandung modalitas psikis. Gangguan berbicara merupakan salah satu kelainan dalam perilaku komunikasi yang ditandai dengan kesalahan bunyi bicara. Perkembangan bahasa erat kaitannya dengan perkembangan berbicara, hal itu menyebabkan adanya gangguan bahasa reseptif dan ekspresif. Menurut Van Riper, gangguan bicara dapat disimpulkan sebagai berikut. Berbicara dikatakan terganggu bila berbicara itu sendiri membawa perhatian yang tidak menyenangkan pada si pembicara, komunikasi itu sendiri terganggu, atau menyebabkan si pembicara menjadi kesulitan untuk menempatkan diri.

Dari gangguan pendengaran dan berbicara tersebut, maka dapat memunculkan kesalahpahaman, kesalahan makna serta kesalahan berbahasa yang dapat dilihat dari bagaimana cara orang normal berkomunikasi dengan orang tunarungu. Orang tunarungu cenderung memperhatikan gerak bibir lawan 
bicaranya saat sedang berinteraksi, berbeda dengan orang normal yang memperhatikan mata lawan bicaranya.

\section{METODE PENELITIAN}

Pendekatan penelitian yang digunakan dalam penelitian ini adalah penelitian kualitatif. Penelitian kualitatif adalah penelitian yang dilakukan pada kondisi obyek alamiah (Sugiyono, 2010: 15). Pendapat senada di kemukakan oleh (Meleong, Lexy J., 2005: 6) Pendekatan kualitatif adalah penelitian yang ber-maksud untuk memahami fenomena tentang apa yang dialami oleh subjek penelitian dengan cara deskripsi dalam bentuk kata-kata dan bahasa pada suatu konteks khusus yang alamiah.

Dengan demikian, laporan penelitian akan berisi kutipan-kutipan data untuk memberi gambaran penyajian laporan tersebut. Data tersebut berasal dari hasil wawancara, catatan lapangan, foto, video dan dokumen pribadi (Meleong, Lexy J., 2005: 11). Dipilihnya metode penelitian kualitatif, penelitian ini diusahakan mengumpulkan data deskriptif yang banyak ditungkan dalam bentuk laporan dan uraian serta tidak mengutamakan angkaangka statistik walaupun tidak menolak data kuantatif. Oleh karena itu, penelitian ini berusaha untuk memperoleh gambaran yang nyata mengenai gangguan berbicara pada penyandang tunarungu di Cinere Depok.

\section{HASIL DAN PEMBAHASAN}

Berikut ini pemaparan yang disampaikan penulis tentang Gangguan Berbicara pada Penyandang Tunarungu di Cinere Depok yang telah dilakukan pengambilan data pada tanggal 23 September 2017.

\section{Data 01}

Pada detik 00:00:30:05 peneliti meminta responden untuk menyebutkan fonem A-Z yang dimulai dari fonem /A/, pada hal ini responden mengiyakan permintaan peneliti. Ketika responden mulai menyebutkan fonem /A/ responden mampu melafalkan fonem /A/ dengan benar. Kemudian pada saat melafalkan fonem /A/ responden menggerakan kedua tangannya dan membentuk gambar segitiga dengan kedua jarinya, yaitu jari telunjuk dan ibu jari dari tangan kanan dan kirinya.

\section{Data 02}

Pada detik 00:00:31:08 responden menyebutkan fonem /B/, pada hal ini responden tidak dapat melafalkan fonem /B/ dengan benar. Responden mengganti fonem $/ \mathrm{B} /$ dengan fonem $/ \mathrm{P} /$. Kemudian pada saat melafalkan fonem /B/ responden menggerakan kedua tangannya dan mengangkat jari telunjuk kiri membuat angka satu, serta mengangkat jari telunjuk, jari tengah, dan jari manis tangan kanan ke arah menyamping dan menyatukannya dengan jari telunjuk yang sebelumnya telah membentuk angka satu.

\section{Data 03}

Pada detik 00:00:32:09 responden menyebutkan fonem $/ \mathrm{C} /$, pada hal ini responden mampu melafalkan fonem /C/ dengan benar. Kemudian pada saat melafalkan fonem $/ \mathrm{C}$ / responden mengangkat hanya dengan satu tangan yaitu tangan kanan, kemudian membentuk setengah lingkaran dengan empat jari disatukan ke arah atas, dan satu jari yaitu ibu jari ke arah bawah.

\section{Data 04}

Pada detik 00:00:33:07 responden menyebutkan fonem /D/, pada hal ini responden mampu melafalkan fonem /D/ dengan benar. Kemudian pada saat 
melafalkan fonem /D/ responden mengangkat kedua tangannya dan menggerakan jari telunjuk kiri membuat angka satu, serta mengangkat jari telunjuk dan ibu jari membentuk setengah lingkaran ke samping kemudian menyatukannya dengan jari telunjuk yang sebelumnya telah membentuk angka satu.

\section{Data 05}

Pada detik 00:00:34:00 responden menyebutkan fonem /E/, pada hal ini responden tidak dapat melafalkan fonem /E/ dengan benar. Responden mengganti fonem /E/ dengan fonem /R/. Kemudian pada saat melafalkan fonem /E/ responden mengangkat hanya satu tangannya yaitu tangan kanan dan menggerakan jari telunjuk, jari tengah, dan jari manis tangan kanan ke arah menyamping.

\section{Data 06}

Pada detik 00:00:34:22 responden menyebutkan fonem $/ F /$, pada hal ini responden mampu melafalkan fonem /F/ dengan benar. Kemudian pada saat me-lafalkan fonem $/ \mathrm{F} /$ responden mengangkat kedua tangannya dan menggerakan jari telunjuk kiri membuat angka satu, serta mengangkat jari telunjuk, jari tengah tangan kanan ke arah me-nyamping dan menyatukannya dengan jari telunjuk yang sebelumnya telah membentuk angka satu, namun kali ini posisi jari telunjuk kiri berada di pangkal jari.

\section{Data 07}

Pada detik 00:00:35:15 responden menyebutkan fonem /G/, pada hal ini responden tidak dapat melafalkan fonem /G/ dengan benar. Responden mengganti fonem /G/ dengan fonem /E/. Kemudian pada saat melafalkan fonem /G/ responden mengangkat kedua tangannya dan mengepalkan kedua tangannya tersebut lalu menyatukannya dengan menaruh kepalan tangan kiri di bawah kepalan tangan kanan, seperti membentuk angka delapan.

\section{Data 08}

Pada detik 00:00:36:07 responden menyebutkan fonem $/ \mathrm{H} /$, pada hal ini responden mampu melafalkan fonem /H/ dengan benar. Kemudian pada saat melafalkan fonem /H/ responden mengangkat kedua tangannya dan menggerakan jari telunjuk kiri membuat angka satu, dan juga mengangkat jari telunjuk kanan membuat angka satu, lalu jari tengah tangan kanan diarahkan ke samping kemudian jari tengah kanan tadi disatukan ke jari telunjuk kiri yang sebelumnya telah membentuk angka satu.

\section{Data 09}

Pada detik 00:00:36:24 responden menyebutkan fonem /I/, pada hal ini responden mampu melafalkan fonem /I/ dengan benar. Kemudian pada saat melafalkan fonem /I/ responden hanya mengangkat satu tangannya saja yaitu hanya tangan kanannya, kemudian responden menggerakan jari kelingkingnya membentuk tegak lurus.

\section{Data 10}

Pada detik 00:00:37:16 responden menyebutkan fonem $/ \mathrm{J} /$, pada hal ini responden mampu melafalkan fonem /J/ dengan benar. Kemudian pada saat melafalkan fonem /J/ responden hanya mengangkat satu tangannya saja yaitu hanya tangan kanannya, kemudian responden menggerakan jari kelingkingnya membentuk tegak lurus lalu mengayunkan jari kelingkingnya ke arah bawah lalu menaikannya kembali tetapi hanya naik setengah ke atas. 


\section{Data 11}

Pada detik 00:00:38:05 responden menyebutkan fonem $/ K /$, pada hal ini responden tidak dapat melafalkan fonem /K/ dengan benar. Responden mengganti fonem $/ \mathrm{K} /$ dengan fonem /A/. Kemudian pada saat melafalkan fonem $/ \mathrm{K} /$ responden mengangkat kedua tangannya dan menggerakan jari telunjuk kiri mem-buat angka satu, kemudian menggerakan jari telunjuk kanannya untuk kemudian melipatnya ke arah dalam, setelah itu menyatukannya dengan jari telunjuk kiri yang sebelumnya telah membentuk angka satu.

\section{Data 12}

Pada detik 00:00:38:17 responden menyebutkan fonem /L/, pada hal ini responden mampu melafalkan fonem /L/ dengan benar. Kemudian pada saat melafalkan fonem /L/ responden hanya mengangkat satu tangannya saja yaitu hanya tangan kanannya, kemudian responden menggerakan jari telunjuk membuat angka satu dan ibu jarinya membentuk tegak lurus ke samping untuk kemudian membentuk lafal /L/, pada fonem /L/ ini jari telunjuk dan ibu jari yang sudah dijelaskan di atas dilakukan secara bersamaan.

\section{Data 13}

Pada detik 00:00:39:10 responden menyebutkan fonem /M/, pada hal ini responden mampu melafalkan fonem /M/ dengan benar. Kemudian pada saat melafalkan fonem /M/ responden mengangkat kedua tangannya dan menggerakan telapak tangan kiri untuk kemudian direntangkan, pada saat itu juga responden mengangkat tiga jari sekaligus yaitu jari telunjuk, jari tengah dan jari manis untuk kemudian disatukan dengan telapak tangan kiri yang tadi sudah direntangkan.

\section{Data 14}

Pada detik 00:00:40:02 responden menyebutkan fonem /N/, pada hal ini responden mampu melafalkan fonem /N/ dengan benar. Kemudian pada saat melafalkan fonem /N/ responden mengangkat kedua tangannya dan menggerakan telapak tangan kiri untuk kemudian direntangkan, pada saat itu juga responden mengangkat dua jari sekaligus yaitu jari telunjuk dan jari tengah untuk kemudian disatukan dengan telapak tangan kiri yang tadi sudah direntangkan. Sebenarnya pada fonem /N/ dalam bahasa isyarat tidak jauh berbeda dengan fonem $/ \mathrm{M} /$, yang membedakan yaitu terletak hanya pada jari tangan kanan. Jika pada fonem /M/ digunakan tiga jari tangan kanan yaitu jari telunjuk, jari tengah, dan jari manis, maka pada fonem /N/ yang digunakan hanya dua jari tangan kanan yaitu jari telunjuk dan jari tengah.

\section{Data 15}

Pada detik 00:00:40:13 responden menyebutkan fonem $/ \mathrm{O} /$, pada hal ini responden mampu melafalkan fonem /O/ dengan benar. Kemudian pada saat melafalkan fonem /O/ responden hanya mengangkat satu tangannya saja yaitu hanya tangan kanannya, kemudian responden membuat lingkaran dengan menggunakan kelima jarinya. Jari telunjuk, jari tengah, jari manis, dan jari kelingking di arahkan ke bawah untuk kemudian disatukan dengan ibu jari.

\section{Data 16}

Pada detik 00:00:41:02 responden menyebutkan fonem $/ \mathrm{P} /$, pada hal ini responden mampu melafalkan fonem /P/ dengan benar. Kemudian pada saat melafalkan fonem $/ \mathrm{P} /$ responden mengangkat kedua tangannya dan menggerakan jari telunjuk kiri membuat angka satu, kemudian menggerakan jari telunjuk dan ibu jari tangan kanannya 
membentuk setengah lingkaran kecil menyamping lalu menyatukannya pada jari telunjuk kiri yang sebelumnya telah membentuk angka satu.

\section{Data 17}

Pada detik 00:00:41:22 responden menyebutkan fonem $/ Q /$, pada hal ini responden tidak dapat melafalkan fonem /Q/ dengan benar. Responden mengganti fonem $/ Q /$ dengan fonem /U/. Kemudian pada saat melafalkan fonem /Q/ responden mengangkat kedua tangannya dan membentuk lingkaran kecil dengan menggunakan jari telujuk dan ibu jari tangan kirinya, kemudian menggerakan jari telunjuk tangan kanannya mem-bentuk angka satu untuk kemudian menyatukannya dengan lingkaran kecil yang sebelumnya telah dibentuk oleh jari telunjuk dan ibu jari.

\section{Data 18}

Pada detik 00:00:42:11 responden menyebutkan fonem $/ \mathrm{R} /$, pada hal ini responden tidak dapat melafalkan fonem /R/ dengan benar. Responden mengganti fonem /R/ dengan fonem /L/. Kemudian pada saat melafalkan fonem /R/ responden hanya mengangkat satu tangannya saja yaitu hanya tangan kanan. Sebenarnya saat melafalkan fonem /R/ ini cukup mudah, yakni cukup menjentikan jari maka dalam bahasa isyarat itu berarti adalah fonem /R/.

\section{Data 19}

Pada detik 00:00:43:04 responden menyebutkan fonem /S/, pada hal ini responden mampu melafalkan fonem /S/ dengan benar. Kemudian pada saat melafalkan fonem /S/ responden mengangkat kedua tangannya dan menggerakan jari telunjuk dan ibu jari tangan kanannya membentuk setengah lingkaran menyamping lalu hal yang sama dilakukan pada jari tangan kanan, tetapi setengah lingkaran tangan kanan di taruh di atas setengah lingkaran tangan kiri atau antar ibu jari tangan kanan bertemu dengan jari telunjuk tangan kiri.

\section{Data 20}

Pada detik 00:00:43:16 responden menyebutkan fonem /T/, pada hal ini responden mampu melafalkan fonem /T/ dengan benar. Kemudian pada saat melafalkan fonem /T/ responden mengangkat kedua tangannya dan menggerakan jari telunjuk kiri membuat angka satu lalu hal yang sama dilakukan pada jari telunjuk kanan, tetapi pada jari telunjuk kanan ini di arahkan menyamping dan diletakan di atas jari telunjuk kiri.

\section{Data 21}

Pada detik 00:00:44:06 responden menyebutkan fonem /U/, pada hal ini responden mampu melafalkan fonem /U/ dengan benar. Kemudian pada saat responden melafalkan fonem /U/ responden hanya mengangkat satu tangannya saja yaitu tangan kanan. Untuk melafalkan fonem /U/ responden menggerakan jari telunjuk dan ibu jarinya yang dibentuk seolah-olah sama dengan fonem /U/.

\section{Data 22}

Pada detik 00:00:44:21 responden menyebutkan fonem /V/, pada hal ini responden tidak dapat melafalkan fonem /V/ dengan benar. Responden mengganti fonem /V/ dengan fonem /P/. Kemudian pada saat melafalkan fonem /V/ responden hanya mengangkat satu tangannya saja yaitu hanya tangan kanannya, kemudian responden menggerakan jari telunjuk dan jari tengahnya membentuk tegak lurus. 


\section{Data 23}

Pada detik 00:00:45:18 responden menyebutkan fonem /W/, pada hal ini responden tidak dapat melafalkan fonem /W/ dengan benar. Responden meng-ganti fonem /W/ dengan fonem /V/. Kemudian pada saat melafalkan fonem /W/ responden mengangkat kedua tangannya dan menggerakan jari telunjuk dan ibu jari tangan kanannya membentuk tanda ceklis, hal yang sama pun dilakukan pada tangan kirinya yaitu membentuk tanda ceklis untuk kemudian responden menyatukan ibu jari tangan kanan dengan ibu jari tangan kiri.

\section{Data 24}

Pada detik 00:00:46:09 responden menyebutkan fonem /X/, pada hal ini responden tidak dapat melafalkan fonem /X/ dengan benar. Responden mengganti fonem /X/ dengan fonem /S/. Kemudian pada saat melafalkan fonem /X/ responden mengangkat kedua tangannya dan menggerakan jari telunjuk tangan kanan membentuk angka satu, hal yang sama pun dilakukan pada jari telunjuk tangan kiri yakni membentuk angka satu untuk kemudian jari telunjuk tangan kanan ditaruh di atas jari telunjuk tangan kiri membentuk menyilang.

\section{Data 25}

Pada detik 00:00:47:03 responden menyebutkan fonem /Y/, pada hal ini responden mampu melafalkan fonem /Y/ dengan benar. Kemudian pada saat melafalkan fonem /Y/ responden hanya mengangkat satu tangannya saja yaitu tangan kanannya untuk kemudian menggerakan jari kelingking dan ibu jarinya membentuk tegak lurus ke atas.

\section{Data 26}

Pada detik 00:00:47:22 responden menyebutkan fonem /Z/, pada hal ini responden mampu melafalkan fonem /Z/ dengan benar. Kemudian pada saat me-lafalkan fonem /Z/ responden hanya mengangkat satu tangannya saja yaitu tangan kanannya untuk kemudian meng-gerakan telapak tangannya membentuk seperti bebek atau telapak tangannya di arahkan ke bawah dan di hadapkan ke samping kanan badan dari responden.

\section{Data 27}

Pada detik 00:00:53:18 peneliti meminta responden untuk menyebutkan huruf vokal, yang mana huruf vokal terdiri dari /A/ /I/ /U/ /E/ dan /O/, pada hal ini responden mengiyakan permintaan peneliti. Ketika responden mulai menyebutkan fonem /A/ responden mampu melafalkan fonem /A/ dengan benar. Kemudian pada saat melafalkan fonem /A/ responden mengangkat kedua tangannya dan membentuk gambar segitiga dengan kedua jarinya, yaitu jari telunjuk dan ibu jari dari tangan kanan dan kirinya.

\section{Data 28}

Pada detik 00:00:54:02 responden menyebutkan fonem /I/, pada hal ini responden mampu melafalkan fonem /I/ dengan benar. Kemudian pada saat melafalkan fonem /I/ responden hanya mengangkat satu tangannya saja yaitu hanya tangan kanannya, kemudian responden menggerakan jari kelingkingnya membentuk tegak lurus.

\section{Data 29}

Pada detik 00:00:54:15 responden menyebutkan fonem /U/, pada hal ini responden mampu melafalkan fonem /U/ dengan benar. Kemudian pada saat responden melafalkan fonem /U/ responden hanya menggerakan satu tangannya saja yaitu tangan kanan. Untuk melafalkan fonem /U/ responden menggunakan jari telunjuk dan ibu 
jarinya yang dibentuk seolah-olah sama dengan fonem /U/.

\section{Data 30}

Pada detik 00:00:55:04 responden menyebutkan fonem /E/, pada hal ini responden tidak dapat melafalkan fonem /E/ dengan benar. Responden mengganti fonem /E/ dengan fonem /R/. Kemudian pada saat melafalkan fonem /E/ responden mengangkat hanya satu tangannya yaitu tangan kanan dan menggerakan jari telunjuk, jari tengah, dan jari manis tangan kanan ke arah menyamping.

\section{Data 31}

Pada detik 00:00:55:26 responden menyebutkan fonem $/ \mathrm{O} /$, pada hal ini responden mampu melafalkan fonem /O/ dengan benar. Kemudian pada saat melafalkan fonem /O/ responden hanya mengangkat satu tangannya saja yaitu hanya tangan kanannya, kemudian responden membuat lingkaran dengan menggunakan kelima jarinya. Jari telunjuk, jari tengah, jari manis, dan jari kelingking di arahkan ke bawah untuk kemudian disatukan dengan ibu jari.

\section{Data 32}

Pada detik 00:01:00:21 peneliti meminta responden untuk menyebutkan huruf konsonan, yang mana huruf konsonan terdiri dari /B/ /C/ /D/ /F/ /G/ /H/ /J/ /K/ /L/ /M/ /N/ /P/ /Q/ /R/ /S/ /7/ $/ \mathrm{V} / / \mathrm{W} / / \mathrm{X} / / \mathrm{Q} /$ dan $/ \mathrm{Z} /$. Responden pun menyebutkan fonem $/ \mathrm{B} /$, pada hal ini responden tidak dapat melafalkan fonem /B/ dengan benar. Responden mengganti fonem $/ \mathrm{B} /$ dengan fonem $/ \mathrm{P} /$. Kemudian pada saat melafalkan fonem /B/ responden mengangkat kedua tangannya dan menggerakan jari telunjuk kiri membuat angka satu, serta mengangkat jari telunjuk, jari tengah, dan jari manis tangan kanan ke arah menyamping dan menyatukannya dengan jari telunjuk yang sebelumnya telah membentuk angka satu.

\section{Data 33}

Pada detik 00:01:01:09 responden menyebutkan fonem $/ \mathrm{C} /$, pada hal ini responden mampu melafalkan fonem /C/ dengan benar. Kemudian pada saat melafalkan fonem $/ \mathrm{C}$ / responden mengangkat hanya dengan satu tangan yaitu tangan kanan, lalu menggerakan tangannya untuk kemudian membentuk setengah lingkaran dengan empat jari disatukan ke arah atas, dan satu jari yaitu ibu jari ke arah bawah.

\section{Data 34}

Pada detik 00:01:02:03 responden menyebutkan fonem /D/, pada hal ini responden mampu melafalkan fonem /D/ dengan benar. Kemudian pada saat me-lafalkan fonem /D/ responden meng-angkat kedua tangannya dan meng-gerakan jari telunjuk kiri membuat angka satu, serta mengangkat jari telunjuk dan ibu jari membentuk setengah lingkaran ke samping kemudian menyatukannya dengan jari telunjuk yang sebelumnya telah membentuk angka satu.

\section{Data 35}

Pada detik 00:01:02:19 responden menyebutkan fonem $/ \mathrm{F} /$, pada hal ini responden mampu melafalkan fonem $/ \mathrm{F} /$ dengan benar. Kemudian pada saat melafalkan fonem $/ \mathrm{F} /$ responden mengangkat kedua tangannya dan menggerakan jari telunjuk kiri membuat angka satu, serta mengangkat jari telunjuk, jari tengah tangan kanan ke arah me-nyamping dan menyatukannya dengan jari telunjuk yang sebelumnya telah membentuk angka satu, namun kali ini posisi jari telunjuk kiri berada di pangkal jari. 


\section{Data 36}

Pada detik 00:01:03:09 responden menyebutkan fonem /G/, pada hal ini responden tidak dapat melafalkan fonem /G/ dengan benar. Responden mengganti fonem /G/ dengan fonem /E/. Kemudian pada saat melafalkan fonem /G/ responden mengangkat kedua tangannya dan mengepalkan kedua tangannya ter-sebut lalu menyatukannya dengan me-naruh kepalan tangan kiri di bawah kepalan tangan kanan, seperti mem-bentuk angka delapan.

\section{Data 37}

Pada detik 00:01:03:27 responden menyebutkan fonem $/ \mathrm{H} /$, pada hal ini responden mampu melafalkan fonem /H/ dengan benar. Kemudian pada saat me-lafalkan fonem /H/ responden meng-angkat kedua tangannya dan meng-gerakan jari telunjuk kiri membuat angka satu, dan juga mengangkat jari telunjuk kanan membuat angka satu, lalu jari tengah tangan kanan diarahkan ke samping kemudian jari tengah kanan tadi disatukan ke jari telunjuk kiri yang sebelumnya telah membentuk angka satu.

\section{Data 38}

Pada detik 00:01:04:14 responden menyebutkan fonem $/ \mathrm{J} /$, pada hal ini responden mampu melafalkan fonem /J/ dengan benar. Kemudian pada saat melafalkan fonem /J/ responden hanya mengangkat satu tangannya saja yaitu hanya tangan kanannya, kemudian responden menggerakan jari kelingkingnya membentuk tegak lurus lalu mengayunkan jari kelingkingnya ke arah bawah lalu menaikannya kembali tetapi hanya naik setengah ke atas.

\section{Data 39}

Pada detik 00:01:05:07 responden menyebutkan fonem $/ K /$, pada hal ini responden tidak dapat melafalkan fonem $/ K /$ dengan benar. Responden mengganti fonem $/ \mathrm{K} /$ dengan fonem /A/. Kemudian pada saat melafalkan fonem /K/ responden mengangkat kedua tangannya dan menggerakan jari telunjuk kiri membuat angka satu, kemudian meng-gerakan jari telunjuk kanannya untuk kemudian melipatnya ke arah dalam, setelah itu menyatukannya dengan jari telunjuk kiri yang sebelumnya telah membentuk angka satu.

\section{Data 40}

Pada detik 00:01:05:24 responden menyebutkan fonem /L/, pada hal ini responden mampu melafalkan fonem /L/ dengan benar. Kemudian pada saat melafalkan fonem /L/ responden hanya mengangkat satu tangannya saja yaitu hanya tangan kanannya, kemudian responden menggerakan jari telunjuk membuat angka satu dan ibu jarinya membentuk tegak lurus ke samping untuk kemudian membentuk lafal /L/, pada fonem /L/ ini jari telunjuk dan ibu jari yang sudah dijelaskan di atas dilakukan secara bersamaan.

\section{Data 41}

Pada detik 00:01:06:15 responden menyebutkan fonem /M/, pada hal ini responden mampu melafalkan fonem /M/ dengan benar. Kemudian pada saat melafalkan fonem /M/ responden mengangkat kedua tangannya dan menggerakan telapak tangan kiri untuk kemudian direntangkan, pada saat itu juga responden mengangkat tiga jari sekaligus yaitu jari telunjuk, jari tengah dan jari manis untuk kemudian disatukan dengan telapak tangan kiri yang tadi sudah direntangkan.

\section{Data 42}

Pada detik 00:01:07:02 responden menyebutkan fonem /N/, pada hal ini 
responden mampu melafalkan fonem /N/ dengan benar. Kemudian pada saat me-lafalkan fonem /N/ responden meng-angkat kedua tangannya dan meng-gerakan telapak tangan kiri untuk kemudian direntangkan, pada saat itu juga responden mengangkat dua jari sekaligus yaitu jari telunjuk dan jari tengah untuk kemudian disatukan dengan telapak tangan kiri yang tadi sudah direntangkan. Sebenarnya pada fonem /N/ dalam bahasa isyarat tidak jauh berbeda dengan fonem $/ \mathrm{M} /$, yang membedakan yaitu terletak hanya pada jari tangan kanan. Jika pada fonem /M/ digunakan tiga jari tangan kanan yaitu jari telunjuk, jari tengah, dan jari manis, maka pada fonem /N/ yang digunakan hanya dua jari tangan kanan yaitu jari telunjuk dan jari tengah.

\section{Data 43}

Pada detik 00:01:07:28 responden menyebutkan fonem $/ \mathrm{P} /$, pada hal ini responden mampu melafalkan fonem /P/ dengan benar. Kemudian pada saat melafalkan fonem $/ \mathrm{P} /$ responden mengangkat kedua tangannya dan menggerakan jari telunjuk kiri membuat angka satu, kemudian menggerakan jari telunjuk dan ibu jari tangan kanannya membentuk setengah lingkaran kecil menyamping lalu menyatukannya pada jari telunjuk kiri yang sebelumnya telah membentuk angka satu.

\section{Data 44}

Pada detik 00:01:08:15 responden menyebutkan fonem $/ Q /$, pada hal ini responden tidak dapat melafalkan fonem /Q/ dengan benar. Responden mengganti fonem $/ \mathrm{Q} /$ dengan fonem /U/. Kemudian pada saat melafalkan fonem /Q/ responden mengangkat kedua tangannya dan membentuk lingkaran kecil dengan menggunakan jari telujuk dan ibu jari tangan kirinya, kemudian menggerakan jari telunjuk tangan kanannya mem-bentuk angka satu untuk kemudian menyatukannya dengan lingkaran kecil yang sebelumnya telah dibentuk oleh jari telunjuk dan ibu jari.

\section{Data 45}

Pada detik 00:01:08:25 responden menyebutkan fonem $/ \mathrm{R} /$, pada hal ini responden tidak dapat melafalkan fonem /R/ dengan benar. Responden mengganti fonem /R/ dengan fonem /E/. Kemudian pada saat melafalkan fonem /R/ responden hanya menggerakan satu tangannya saja yaitu hanya tangan kanan. Sebenarnya saat melafalkan fonem /R/ ini cukup mudah, yakni cukup menjentikan jari maka dalam bahasa isyarat itu berarti adalah fonem /R/.

\section{Data 46}

Pada detik 00:01:09:17 responden menyebutkan fonem /S/, pada hal ini responden mampu melafalkan fonem /S/ dengan benar. Kemudian pada saat melafalkan fonem /S/ responden mengangkat kedua tangannya dan menggerakan jari telunjuk dan ibu jari tangan kanannya membentuk setengah lingkaran menyamping lalu hal yang sama dilakukan pada jari tangan kanan, tetapi setengah lingkaran tangan kanan di taruh di atas setengah lingkaran tangan kiri atau antar ibu jari tangan kanan bertemu dengan jari telunjuk tangan kiri.

\section{Data 47}

Pada detik 00:01:10:05 responden menyebutkan fonem /T/, pada hal ini responden mampu melafalkan fonem /T/ dengan benar. Kemudian pada saat melafalkan fonem /T/ responden mengangkat kedua tangannya dan menggerakan jari telunjuk kiri membuat 
angka satu lalu hal yang sama dilakukan pada jari telunjuk kanan, tetapi pada jari telunjuk kanan ini di arahkan menyamping dan diletakan di atas jari telunjuk kiri.

\section{Data 48}

Pada detik 00:01:10:24 responden menyebutkan fonem $/ \mathrm{V} /$, pada hal ini responden mampu melafalkan fonem /V/ dengan benar. Kemudian pada saat melafalkan fonem /V/ responden hanya mengangkat satu tangannya saja yaitu hanya tangan kanannya, kemudian responden menggerakan jari telunjuk dan jari tengahnya membentuk tegak lurus.

\section{Data 49}

Pada detik 00:01:11:11 responden menyebutkan fonem /W/, pada hal ini responden tidak dapat melafalkan fonem /W/ dengan benar. Responden meng-ganti fonem /W/ dengan fonem /V/. Kemudian pada saat melafalkan fonem /W/ responden mengangkat kedua tangannya dan menggerakan jari telunjuk dan ibu jari tangan kanannya membentuk tanda ceklis, hal yang sama pun dilakukan pada tangan kirinya yaitu membentuk tanda ceklis untuk kemudian responden menyatukan ibu jari tangan kanan dengan ibu jari tangan kiri.

\section{Data 50}

Pada detik 00:01:12:00 responden menyebutkan fonem /X/, pada hal ini responden tidak dapat melafalkan fonem /X/ dengan benar. Responden mengganti fonem /X/ dengan fonem /S/. Kemudian pada saat melafalkan fonem /X/ responden mengangkat kedua tangannya dan menggerakan jari telunjuk tangan kanan membentuk angka satu, hal yang sama pun dilakukan pada jari telunjuk tangan kiri yakni membentuk angka satu untuk kemudian jari telunjuk tangan kanan ditaruh di atas jari telunjuk tangan kiri membentuk menyilang.

\section{Data 51}

Pada detik 00:01:12:17 responden menyebutkan fonem /Y/, pada hal ini responden mampu melafalkan fonem /Y/ dengan benar. Kemudian pada saat melafalkan fonem $/ \mathrm{Y} /$ responden hanya menggunakan satu tangannya saja yaitu tangan kanannya untuk kemudian meng-gerakan jari kelingking dan ibu jarinya.

\section{Data 52}

Pada detik 00:01:13:09 responden menyebutkan fonem /Z/, pada hal ini responden mampu melafalkan fonem /Z/ dengan benar. Kemudian pada saat melafalkan fonem /Z/ responden hanya menggunakan satu tangannya saja yaitu tangan kanannya untuk kemudian meng-gerakan telapak tangannya membentuk seperti bebek atau telapak tangannya di arahkan ke bawah dan di hadapkan ke samping.

\section{Data 53}

Peneliti : Assalamu'alaikum wr.wb. Perkenalkan nama saya Mardiana, program studi Sastra Indonesia, fakultas Sastra, Universitas Pamulang, 2014. Kali ini saya akan menganalisis tentang "Gangguan Berbicara Pada Penyandang Tunarungu di Cinere". Berikut liputan wawancaranya.

Septi : (melambaikan tangan ke kamera)

Pada detik 00:00:18:02 berdasarkan data di atas, tahap selanjutnya adalah peneliti mulai mengadakan sesi wawancara, dan setelah peneliti memperkenalkan diri dan akan memulai 
sesi wawancara dengan responden dan melihat urutan pertanyaan agar berjalan semestinya, responden memberikan "(lambaian tangan ke kamera)" sambil tersenyum. Hal ini sebagai awalan yang cukup baik, yang mana ini berarti responden dengan senang hati melakukan sesi wawancara dan bersedia untuk direkam serta responden memiliki percaya diri yang tinggi dan tidak malu.

\section{Data 54}

Peneliti : Bisa dilafalkan huruf A sampai Z?

Septi : (mengangguk sambil menunjuk ke arah dirinya) jawaban?

Peneliti : Bicara

Septi : Bicara (mengangguk)

A, p, c, d, r, f, e, h, i, j, a, l, $\mathrm{m}, \mathrm{n}, \mathrm{o}, \mathrm{p}, \mathrm{u}, \mathrm{l}, \mathrm{s}, \mathrm{t}, \mathrm{u}, \mathrm{p}, \mathrm{v}, \mathrm{s}$, $\mathrm{y}, \mathrm{z}$

$\begin{array}{ccc}\text { Pada } & \text { detik } & 00: 00: 26: 00 \\ \text { 00:00:27:21 } & \text { saat peneliti } & \text { mulai } \\ \text { mengajukan } & \text { pertanyaan } & \text { "Bisa }\end{array}$ dilafalkan huruf A sampai Z?", Septi menjawab dengan cara mengangguk dan menunjuk ke arah dirinya sambil berkata /JAWABAN/ atau memiliki fonem /J/ /A/ /W/ /A/ /B/ /A/ /N/, yang mana dalam bahasa isyarat ialah mempertegas jawaban septi apakah jawabnya bahasa isyarat atau berbicara. Selanjutnya peneliti mempertegasnya dengan berkata /BICARA/ dan Septi pun menjawab dengan cara berbahasa lisan dan isyarat yaitu dengan mengeluarkan kata /BICARA/ atau memiliki fonem /B/ /I/ /C/ /A/ /R/ /A/ lalu mengangguk, yang artinya ia paham dan mengerti maksud dari responden, lalu Septi pun melafalkan fonem A-Z dengan menggunakan bahasa isyarat dan dengan melafalkannya menggunakan bahasa lisan.
Dari apa yang telah peneliti tanyakan diketahui bahwa ada sebagian jawaban Septi yang tidak salah ataupun keliru, hanya saja pada saat melafalkan fonem $\mathrm{A}-\mathrm{Z}$ ada beberapa fonem yang tidak sesuai, misalnya pada fonem /B/ berubah fonem menjadi $/ \mathrm{P} /$, fonem $/ \mathrm{E} /$ berubah fonem menjadi $/ \mathrm{R} /$, fonem $/ \mathrm{G} /$ berubah fonem menjadi /E/ dan lain sebagainya, yang dapat dilihat pada data-data di atas.

\section{Data 55}

Peneliti : Kalau huruf vokal?

Septi : Voal? (mengangguk)

Peneliti : Iya

Septi : a, i, u, e, o

Pada detik 00:00:51:21 00:00:55:20 peneliti meminta responden melafalkan huruf vokal, dan Septi pun mempertegas pertanyaan dengan mengulang kata /VOKAL/ yang terdiri dari fonem /V/ /O/ /K/ /A/ /L/ tetapi pada saat Septi melafalkan kata vokal, Septi menghilangkan fonem $/ \mathrm{K} /$ sehingga menjadi /VOAL/ atau /V/ /O/ /A/ /L/. Selanjutnya peneliti menjawab pertanyaan Septi dengan mengucapkan kata /IYA/ dan Septi pun langsung melafal-kan huruf vokal yaitu /A/ /I/ /U/ /E/ /O/ dengan cara mengangkat satu tangannya saja dan menggerakan jarijarinya yang kemudian membentuk huruf /A/ /I/ /U/ /E/ /O/.

\section{Data 56}

Peneliti : Huruf konsonan?

Septi : Sonan?

$$
\begin{aligned}
& P, c, d, f, e, h, j, a, 1, m, \\
& \text { n, p, u, e, s, t, v, v, s, y, z }
\end{aligned}
$$

Pada detik 00:00:57:19 sampai menit ke 00:01:13:09 peneliti meminta responden melafalkan huruf konsonan, dan Septi pun mempertegas pertanyaan kembali dengan mengulang kata /KONSONAN/ yang terdiri dari fonem 
/K/ /O/ /N/ /S/ /O/ /N/ /A/ /N/ tetapi pada saat Septi melafalkan kata /KONSONAN/, Septi menghilangkan huruf konsonan /K/ dan /N/ serta menghilangkan huruf vokal $/ \mathrm{O} /$ sehingga menjadi /S/ /O/ /N/ /A/ /N/ atau /SONAN/. Selanjutnya Septi pun langsung melafalkan huruf konsonan yaitu /B/ /C/ /D/ /F/ /G/ /H/ /J/ /K/ /L/ $/ \mathrm{M} / / \mathrm{N} / / \mathrm{P} / / \mathrm{Q} / / \mathrm{R} / / \mathrm{S} / / \mathrm{T} / / \mathrm{V} / / \mathrm{W} / / \mathrm{X} /$ /Y/ IZ/ dengan cara mengangkat kedua tangannya dan menggerakan jari-jarinya yang kemudian membentuk huruf /B/ /C/ /D/ /F/ /G/ /H/ /J/ /K/ /L/ /M/ /N/ /P/ /Q/ /R/ /S/ /T/ /V/ /W/ /X/ /Y/ /Z/. Tetapi pada saat melafalkan huruf konsonan ini Septi mengalami sedikit beberapa kesulitan seperti pada fonem $/ \mathrm{B} /$ berubah fonem menjadi $/ \mathrm{P} /$, fonem $/ \mathrm{K} /$ berubah fonem menjadi /A/, fonem $/ \mathrm{Q} /$ berubah fonem menjadi /U/ dan lain sebagainya, yang dapat dilihat pada data-data di atas.

\section{Data 57}

$\begin{array}{ll}\text { Peneliti } & \text { Namanya siapa? } \\ \text { Septi } & \text { Nama caya s, m, p, t, i. } \\ & \text { Cepti }\end{array}$

Peneliti : Septi

Septi : (mengangguk)

Berdasarkan data di atas, pada menit 00:01:17:16 - 00:01:22:07 peneliti menanyakan nama dari Septi. Septi pun menjawab dengan perpaduan bahasa lisan dan bahasa isyarat. Saat melafalkan kata /NAMA/ atau memiliki fonem /N/ /A/ /M/ /A/, Septi tidak mengalami kesulitan dalam pelafalan. Untuk meng-ungkapkan kata /NAMA/ responden menunjuk ke arah telapak tangan kirinya yang mana ia juga menggerakan jari telunjuk dan ibu jari kanannya dari luar ke dalam. Kemudian saat menjelaskan kata /SAYA/ atau memiliki fonem /S/ /A/ /Y/ /A/, responden mengganti huruf konsonan
/S/ dengan /C/ sehingga menjadi /CAYA/ atau berfonem /C/ /A/ /Y/ /A/. Untuk mengungkapkan kata /SAYA/ Septi menunjuk dirinya sendiri. Kemudian responden mengeja/melafalkan kata /SEPTI/ atau memiliki fonem /S/ /E/ /P/ /T/ /I/, Septi mengeja namanya menggunakan bahasa isyarat, dan pada saat mengeja kata /SEPTI/, responden mengganti huruf vokal /E/ dengan /M/ sehingga menjadi /SMPTI/ atau ber-fonem /S/ /M/ /P/ /T/ /I/. Selanjutnya peneliti menegaskan kembali nama dari Septi. Septi pun mengangguk, arti dari mengangguk ini adalah sebuah bahasa tubuh yang secara refleks atau tidak sengaja dibuat oleh responden. Mengangguk berarti benar atau iya.

\section{SIMPULAN}

Pertama, pada tuturan fonologi yang diucapkan pada subjek tunggal yang mengalami gangguan berbicara pada penyandang tunarungu usia 22 tahun yang bernama Lindya Septiani. Saat pertama kali memulai sesi wawancara, peneliti meminta responden untuk melafalkan huruf alfabet, huruf vokal, huruf konsonan dan terakhir baru melakukan wawancara. Pada huruf alfabet, peneliti memperhatikan setiap huruf yang dilafalkan oleh responden, sehingga dapat disimpulkan bahwa tuturan yang diucapkan responden mengalami kesulitan pada fonem-fonem berikut ini: $\mathrm{B}$ berubah menjadi $\mathrm{P}, \mathrm{E}$ berubah menjadi $R, G$ berubah menjadi $\mathrm{E}, \mathrm{K}$ berubah menjadi $\mathrm{A}, \mathrm{Q}$ berubah menjadi $\mathrm{U}, \mathrm{R}$ berubah menjadi $\mathrm{L}, \mathrm{V}$ berubah menjadi $\mathrm{P}, \mathrm{W}$ berubah menjadi $\mathrm{V}$, dan $\mathrm{X}$ berubah menjadi $\mathrm{S}$. Sedangkan pada huruf vokal, responden tidak mengalami kesulitan dalam pengucapan atau pelafalan. Selanjutnya pada huruf konsonan, responden mengalami kesulitan pada fonem-fonem 
berikut ini: $\mathrm{B}$ berubah menjadi $\mathrm{P}, \mathrm{G}$ berubah menjadi $\mathrm{E}, \mathrm{K}$ berubah menjadi A, Q berubah menjadi U, R berubah menjadi $\mathrm{E}, \mathrm{W}$ berubah menjadi $\mathrm{V}$, dan $\mathrm{X}$ berubah menjadi $\mathrm{S}$. Terakhir yaitu pada sesi wawancara, responden mengalami kesulitan dalam pelafalan karena responden menghilangkan fonem-fonem berikut ini: $\mathrm{K}, \mathrm{O}, \mathrm{N}, \mathrm{H}$, $\mathrm{G}, \mathrm{R}, \mathrm{E}, \mathrm{S}, \mathrm{Y}, \mathrm{B}, \mathrm{A}, \mathrm{I}, \mathrm{dan} \mathrm{T}$. Responden juga mengganti fonemfonem berikut ini: E, S, R, K, dan A. Hal ini terjadi karena responden mengalami gangguan berbicara yang diakibatkan karena sistem pendengarannya yang sudah tidak berfungsi dan juga saraf pada otaknya sewaktu kecil tidak bisa menangkap setiap tuturan yang diucapkan orang lain yang berakibat pada sulitnya responden memahami dan melafalkan suatu huruf, frasa, klausa, atau bahkan kalimat dengan baik. Namun, ada juga huruf, frasa, atau klausa yang dilafalkan responden yang diucapkannya dengan baik dan jelas.

Kedua, pada bentuk bahasa isyarat yang dilakukan oleh responden sebenar-nya sudah sesuai dengan Bahasa Isyarat Indonesia (BISINDO) karena responden sejak duduk di bangku taman kanan-kanan sudah masuk ke sekolah yang memang khusus diperuntukan untuk penyandang disabilitas. Responden juga lebih sering menggunakan bahasa isyarat jika sedang berada di lingkungan sesama tunarungu atau tuli, sedangkan di lingkungan luar atau berada di antara orang normal, responden lebih memilih untuk membaca bahasa bibir orang normal tersebut. Hal itu pula yang dilakukan responden kepada peneliti pada saat sesi wawancara sedang berlangsung, yaitu responden membaca bahasa bibir dari peneliti. Responden juga mempermudah peneliti dalam memahami setiap gerakan yang dilakukan responden dengan cara menganggu- kan kepala, menggelengkan kepala, memegang kepala, dan melambaikan tangan.

\section{DAFTAR PUSTAKA}

Chaer, A. (2003). Psikolinguistik: Kajian Teoretik. Jakarta: PT Rineka Cipta

Dardjowidjojo, S. (2003). Psikolinguistik: Pengantar Pemahaman Bahasa Manusia. Jakarta: Yayasan Pustaka Obor Indonesia.

Keraf, G. (1997). Komposisi: Sebuah Pengantar Kemahiran Bahasa. Ende-Flores: Nusa Indah.

Khabori, M. A., dan Khandekar, R., (2004). The Prevalence and Causes of Hearing. Impairment in Oman. International Journal of Audiology, 486-492.

Moloeng, L. J. (2005). Metodologi Penelitian Kualitatif. Bandung: PT. Remaja Rosdakarya.

(2010). Metodologi penelitian kualitatif. Bandung: PT Remaja Rosdakarya.

Sugiyono (2010). Metode Penelitian Kuantitatif Kualitatif dan $R \& D$. Bandung: Alfabeta.

- (2011). Metode Penelitian Kuantitatif Kualitatif dan R\&D. Bandung: Alfabeta.

Suriasumantri, J. (1998). Ilmu dalam Perspektif. Jakarta: Yayasan Obor.

Winarsih, M. (2007). Intervensi Dini bagi Anak Tunarungu dalaam Pemerolehan Bahasa. Jakarta: Depdiknas. 